\title{
Catalytic Degradation of Diatrizoate by Persulfate Activation with Peanut Shell Biochar-Supported Nano Zero-Valent Iron in Aqueous Solution
}

\author{
Jian $\mathrm{Xu}^{1,2}$, Xueliang Zhang ${ }^{2,3}$, Cheng Sun ${ }^{1, *}$, Huan He ${ }^{4}$, Yuxuan Dai ${ }^{1}$, Shaogui Yang ${ }^{4, *}$, \\ Yusuo Lin ${ }^{2}$, Xinhua Zhan ${ }^{3}$, Qun $\mathrm{Li}^{2}$ and Yan Zhou ${ }^{2}$ \\ 1 State Key Laboratory of Pollution Control and Resource Reuse, School of the Environment, \\ Nanjing University, Nanjing 210023, China; xujian@nies.org (J.X.); daiyuxuan@smail.nju.edu.cn (Y.D.) \\ 2 Nanjing Institute of Environmental Sciences, Ministry of Environmental Protection, Nanjing 210042, China; \\ 2016103039@njau.edu.cn (X.Z.); lys@nies.org (Y.L.); liqun@nies.org (Q.L.); zhouyan@nies.org (Y.Z.) \\ 3 College of Resources and Environmental Sciences, Nanjing Agricultural University, Nanjing 210095, China; \\ xhzhan@njau.edu.cn \\ 4 School of Environment, Nanjing Normal University, Nanjing 210023, China; huanhe@njnu.edu.cn \\ * Correspondence: envidean@nju.edu.cn (C.S.); yangsg@njnu.edu.cn (S.Y.)
}

Received: 6 August 2018; Accepted: 1 September 2018; Published: 6 September 2018

\begin{abstract}
An emerging pollutant, diatrizoate (DTZ) has been frequently detected in aqueous solution. Unique reticular peanut shell biochar (BC)-supported nano zero-valent iron (nZVI) composite (nZVI/BC) was successfully synthesized and used as a catalyst for activating persulfate (PS) to promote the removal of DTZ. The structure and morphology of the nanocomposite materials were characterized by scanning electron microscopy, X-ray diffraction, Brunauer-Emmett-Teller measurements, and Fourier transform infrared spectroscopy. The degradation of DTZ $\left(20 \mathrm{mg} \mathrm{L}^{-1}\right)$ was achieved by activating PS with the nanocomposite material. The removal of DTZ reached nearly $100 \%$ using $25 \mathrm{mM} \mathrm{PS}$ and $0.45 \mathrm{~g} \mathrm{~L}^{-1} \mathrm{nZVI} / 2 \mathrm{BC}$ (mass ratio of $\mathrm{nZVI}$ and $\mathrm{BC}$ at 1:2) nanocomposite material at $\mathrm{pH} 3.0$ and $25^{\circ} \mathrm{C}$. Influencing factors, such as dosages of nZVI/2BC and PS, temperature, and $\mathrm{pH}$ were also investigated. The mechanisms of PS activation with nZVI/2BC were discussed, including $\mathrm{BC}$ property, electron transfer, and the identification of free radicals in the reaction. The findings demonstrated that nZVI/BC-PS (peanut shell BC-supported nZVI activating PS) is a promising material for the treatment of refractory organic pollutants.
\end{abstract}

Keywords: nano zero-valent iron; peanut shell biochar; persulfate activated; diatrizoate; degradation

\section{Introduction}

With the rapid development of medicine, considerable attention is being paid to pharmaceuticals and personal care products (PPCPs), which are unfortunately also emerging contaminants (ECs) [1,2]. Iodinated contrast media (ICM) is a typical PPCP, which is used to enhance organs and blood vessel image observation effects [3]. ICM was widely detected in hospital and domestic wastewater, treated wastewater effluent, groundwater, surface water, and even drinking water, ranging from $\mathrm{ng} \mathrm{L}^{-1}$ to $\mu \mathrm{g} \mathrm{L}^{-1}$ worldwide due to its abuse and improper disposal $[4,5]$. China is one of the largest consumers of ICM in the world, with total ICM concentrations in Taihu Lake and the Huangpu River ranging from 88.7 to $131 \mathrm{ng} \mathrm{L}^{-1}$ and 102 to $252 \mathrm{ng} \mathrm{L}^{-1}$, respectively [6]. Diatrizoate (DTZ), an abundant ionic ICM, is identified as a refractory organic pollutant due to it being highly polar and chemically inert $[7,8]$, which exceeds the self-purification capacity of the environment and hence may result in potential hazards to living species in various ways. For example, previous studies reported that DTZ led to nephrotoxic effects and decreased thyroid homeostasis of organisms $[9,10]$. Therefore, it is necessary 
to find out efficient treatment technologies to remove DTZ from the aquatic environment. However, there have been few reports on DTZ degradation so far.

Advanced oxidation processes (AOPs) based on hydroxyl radical $\left(\mathrm{HO}^{\bullet}\right)\left(\mathrm{E}_{0}=1.8-2.7 \mathrm{~V}\right)$ have been recognized as efficient techniques for the remediation of recalcitrant organic pollutants [11], while AOPs based on sulfate radical $\left(\mathrm{SO}_{4}{ }^{--}\right)$have stronger oxidation ability $\left(\mathrm{E}_{0}=2.5-3.1 \mathrm{~V}\right)$. Compared with hydroxyl radical $\left(\mathrm{HO}^{\bullet}\right)$, sulfate radical has longer life, and sulfate radical is also more selective than hydroxyl radical [11]. Many researchers have made efforts to produce $\mathrm{SO}_{4}{ }^{\bullet-}$ by activating persulfate (PS) for the removal and mineralization of refractory contaminants. Up to now, heat, UV light, transition metals, ultrasound, and alkalization have been considered to be the main activation methods [12,13].

Among the above-mentioned activation methods, $\mathrm{Fe}$, a cheap and non-toxic transition metal, is considered as an efficient material in activating PS. Compared to $\mathrm{Fe}^{3+}$ and $\mathrm{Fe}^{2+}$, which have low efficiency in practice [14,15], zero-valent iron (ZVI) is widely known as an environmentally friendly material and can act as an alternative source of $\mathrm{Fe}^{2+}$ by continuous electron transfer [15]. Many studies have been carried out using ZVI to activate PS so as to effectively produce $\mathrm{SO}_{4}{ }^{\bullet-}$ for removing organic pollutants, including 2,4-dinitrotoluene [16], p-chloroaniline [17], Acid Orange 7 [18], trichloroethylene [19], and so forth. This is because ZVI (especially nano-ZVI) has a small particle size, large specific surface area, and strong reactivity [20]. However, due to its high surface energy and intrinsic magnetic interactions, nano-ZVI (nZVI) is easy to aggregate into microscale particles, which decreases the property of its activation [21]. Various strategies have been used to try and disperse nanomaterials, such as by using surface coating and green synthesis methods [22,23], and using supporting materials such as graphene, resin, active carbon, and zeolite [24-27].

Biochar (BC) is a rich and inexpensive material, made in an anaerobic environment by combusting biomass $[28,29]$. Biochar has been proposed as an environmentally friendly remedial material for a variety of environmental applications [30,31]. Through pyrolysis, a porous structure is formed in BC, which can be used to disperse and stabilize nZVI [32,33]. Abundant oxygen-containing functional groups, including hydroxyl $(-\mathrm{OH})$ and carboxyl $(-\mathrm{COOH})$, can also be observed on the surface of $\mathrm{BC}$. These functional groups are able to activate PS, along with nZVI [34,35]. In addition, BC has a large surface area and excellent ion exchange capacity, and hence can adsorb many heavy metal ions and organic contaminants. Adsorptions of Reactive Black 5 dye, $\mathrm{Cu}^{2+}, \mathrm{Pb}^{2+}$, and $\mathrm{Cr}^{3+}$ have been reported by peanut shell $\mathrm{BC}$ in recent years [36-38]. The mesh structure of peanut shell $\mathrm{BC}$ may be easier to disperse the nZVI particle, while other commonly porous BCs are prone to blocking $[1,33,39]$, and nZVI supported on peanut shell BC composite material (nZVI/BC) with a mesh structure should have excellent degradation ability. The development of biological waste-based innovative materials for environmental remediation could greatly help conquest widespread environmental pollution problems in developing countries like China [40,41], while rendering relatively low economic cost and environmental footprints [42,43]. However, up to now, the study of nZVI supported on peanut shell $\mathrm{BC}$ composite material with a mesh structure has been rarely reported.

The aims of this work are: (1) to prepare and characterize BC and nZVI/BC composites; (2) to evaluate the synergetic effects between Fe and BC on activation PS, and the activation ability of PS on the degradation of DTZ with nZVI/BC composite in aqueous solution; (3) to recognize the significant influencing factors that affect its activation ability and optimize the conditions in DTZ removal; (4) to explore the PS activation mechanism by nZVI/BC composites. 


\section{Materials and Methods}

\subsection{Materials}

Sodium diatrizoate hydrate $\left(\mathrm{C}_{11} \mathrm{H}_{8} \mathrm{I}_{3} \mathrm{~N}_{2} \mathrm{NaO}_{4} \cdot \mathrm{xH}_{2} \mathrm{O}\right.$, CAS 737-31-5, $\left.>98 \%\right)$, sodium borohydride $\left(\mathrm{NaBH}_{4},>98 \%\right)$, iron (II) sulfate heptahydrate $\left(\mathrm{FeSO}_{4} \cdot 7 \mathrm{H}_{2} \mathrm{O},>99 \%\right)$, and sodium persulfate $\left(\mathrm{Na}_{2} \mathrm{~S}_{2} \mathrm{O}_{8}\right.$, $>99 \%$ ) were provided by the Sigma company in China. Only high-purity analytical-grade chemicals and deionized water $(18.25 \mathrm{M} \Omega \cdot \mathrm{cm})$ was used in this study.

\subsection{Experiments}

\subsubsection{Synthesis Process of BC and nZVI/BC}

The raw material peanut shells were collected from Nanjing, Jiangsu province, China. The obtained materials were washed by deionized water several times to remove impurities and then dried in an oven at $70{ }^{\circ} \mathrm{C}$ until a constant weight was achieved. After grinding by a ball mill and passing through a 100-mesh sieve, the materials were pyrolyzed in a muffle furnace under an oxygen-limited condition at $350{ }^{\circ} \mathrm{C}$ for $2 \mathrm{~h}$. The cooling-off $\mathrm{BC}$ was treated with $1 \mathrm{~mol} \mathrm{~L}^{-1} \mathrm{HCl}$ for $12 \mathrm{~h}$ and washed three times with deionized water.

The nZVI/BC was prepared by reducing ferrous iron $\left(\mathrm{FeSO}_{4} \cdot 7 \mathrm{H}_{2} \mathrm{O}\right)$ with sodium borohydride $\left(\mathrm{NaBN}_{4}\right)$ [44]. To take nZVI/BC mass ratios of $1: 1$ as an example, $5.0 \mathrm{~g} \mathrm{FeSO} \cdot \mathrm{H}_{2} \cdot 7 \mathrm{O}$ and $1.0 \mathrm{~g} \mathrm{BC}$ were put in a 3 mouth-flask with $250 \mathrm{~mL}$ deionized water and stirred by a mechanical agitator for $1 \mathrm{~h}$ to obtain a homogenous solution. Then, pure $\mathrm{N}_{2}$ was injected into the flask to remove the air until the end of the synthesis. After that, $50 \mathrm{~mL} 20 \mathrm{mg} \mathrm{L}^{-1} \mathrm{NaBH}_{4}$ solution at the separating funnel was added dropwise for the reduction of $\mathrm{Fe}^{2+}$ to $\mathrm{nZVI}$, being stirred vigorously for $1 \mathrm{~h}$. A leachate separator was used to separate the $\mathrm{nZVI} / \mathrm{BC}$ particles from the solution and washed several times with ethanol and deionized water in the nitrogen atmosphere. Lastly, clean nZVI/BC nanocomposite was dried in the oven at $60^{\circ} \mathrm{C}$, also under the protection of nitrogen. Two other kinds of nZVI/BC composites with different mass ratios at 1:2 and 1:3 were also prepared based on the $\mathrm{nZVI} / \mathrm{BC}$ mass ratio of 1:1 procedure, through using $5.0 \mathrm{~g} \mathrm{FeSO}_{4} \cdot 7 \mathrm{H}_{2} \mathrm{O}: 2.0 \mathrm{~g} \mathrm{BC}$ and $5.0 \mathrm{~g} \mathrm{FeSO}_{4} \cdot 7 \mathrm{H}_{2} \mathrm{O}: 3.0 \mathrm{~g} \mathrm{BC}$, respectively. The three types of nZVI/BC with different mass ratios $(1: 1,1: 2$, and 1:3) were labeled as nZVI/1BC, $\mathrm{nZVI} / 2 \mathrm{BC}$, and $\mathrm{nZVI} / 3 \mathrm{BC}$, respectively.

\subsubsection{Characterizations}

The Brunauer-Emmett-Teller (BET) surface areas and pore size distribution of these samples were measured by nitrogen adsorption (ASAP 2020, Micrometrics, Norcross, GA, USA). The scanning electron microscopy (SEM, QUANTA FEG 250, FEI, Hillsboro, OR, USA), equipped with energy dispersive $\mathrm{X}$-ray spectrometry, was used to observe the morphology and structure of the nZVI, BC, and $\mathrm{nZVI} / \mathrm{BC}$ at an accelerating voltage of $5 \mathrm{kV}$. The possible crystalline structures and compositions of these samples were examined through the X-ray diffraction (XRD, XRD-6000, Shimadzu, Japan) test with the $2 \theta$ range at $5^{\circ}-75^{\circ}$. Functional $B C$ groups were characterized by Fourier transform infrared spectroscopy (FT-IR, Nexus 870 , Nicolet, WI, USA) spectra, with the wave numbers ranging from 400 to $4000 \mathrm{~cm}^{-1}$.

\subsubsection{DTZ Adsorption and Degradation}

Before degradation, $0.45 \mathrm{~g} \mathrm{~L}^{-1}$ peanut shell $\mathrm{BC}, \mathrm{nZVI} / 1 \mathrm{BC}, \mathrm{nZVI} / 2 \mathrm{BC}$, and $\mathrm{nZVI} / 3 \mathrm{BC}$ were added into the $200 \mathrm{~mL}$ test solutions prepared with deionized water $\left(20 \mathrm{mg} \mathrm{L}^{-1} \mathrm{DTZ}\right)$ in $250 \mathrm{~mL}$ conical flasks at $25^{\circ} \mathrm{C}$ with an automatic rotation of $125 \mathrm{rpm}$, respectively, to examine the adsorption of DTZ separately. After no significant difference in adsorption capacity was found, batch experiments of DTZ degradation were performed by adding PS under the previous conditions.

To assess the degradation ability of DTZ, the predetermined amount of activators (nZVI, BC, $\mathrm{nZVI} / \mathrm{BC}$ ) with $25 \mathrm{mM}$ PS were used. To determine the effect of the mass ratio on DTZ degradation, 
nZVI/BC with different ratios of 1:1, 1:2, and 1:3 were studied. To investigate the impact of the $\mathrm{nZVI} / \mathrm{BC}$ and PS dosage, $0.15 \mathrm{~g} \mathrm{~L}^{-1}, 0.30 \mathrm{~g} \mathrm{~L}^{-1}, 0.45 \mathrm{~g} \mathrm{~L}^{-1}$, and $0.60 \mathrm{~g} \mathrm{~L}^{-1} \mathrm{nZVI} / \mathrm{BC}$ and $5 \mathrm{mM}$, $15 \mathrm{mM}, 25 \mathrm{mM}$, and $50 \mathrm{mM}$ PS were used, respectively. To investigate the effect of $\mathrm{pH}$ on DTZ degradation, $\mathrm{pH}$ values of aqueous solutions were adjusted to 3.0, 5.0, 7.0, 9.0, and 11.0, with $0.1 \mathrm{M}$ sodium hydroxide $(\mathrm{NaOH})$ or $0.1 \mathrm{M}$ sulfuric acid $\left(\mathrm{H}_{2} \mathrm{SO}_{4}\right)$. To explore the effect of temperature on the oxidation of DTZ in the nZVI/BC-PS system, the temperature was regulated at $15{ }^{\circ} \mathrm{C}, 25^{\circ} \mathrm{C}, 35^{\circ} \mathrm{C}$, and $45^{\circ} \mathrm{C}$, respectively. Reusability experiments for the activator (nZVI/2BC) were performed for five cycles under the optimized test conditions. After each recycle, the composite material was filtered and washed with deionized water several times and then cleaned with ethanol before being dried. At selected time intervals, a $800 \mu \mathrm{L}$ sample was withdrawn and filtered through $0.22 \mu \mathrm{m}$ syringe filters and immediately put into liquid vials with $200 \mu \mathrm{L}$ sodium thiosulfate to inhibit reactions prior to analysis.

\subsubsection{Analytical Methods}

The concentrations of DTZ were determined by a 1200 high-performance liquid chromatograph (HPLC, 1200 series, Agilent, Santa Clara, CA, USA) equipped with a UV detector at $237 \mathrm{~nm}$. The HPLC column used was a reversed-phase $\mathrm{C} 18$ column, and the temperature of the column was maintained at $30{ }^{\circ} \mathrm{C}$. The mobile phase was methanol water $(20: 80, v / v)$ with a flow rate at $1 \mathrm{~mL} \mathrm{~min}^{-1}$ [8]. $\mathrm{Fe}^{2+}$ produced by the reaction was determined using a SHIMADZU UV-1800 spectroscopy at $510 \mathrm{~nm}$ by using the 1,10-phenanthroline colorimetric method, and $\mathrm{Fe}^{3+}$ was tested by the reduction with ascorbic acid [45]. PS concentration was analyzed by UV-vis spectrophotometer with KI [46]. The mineralization of DTZ was measured by total organic carbon, using the TOC (Total organic carbon) analyzer (TOC-5000, Shimadzu, Japan).

\section{Results and Discussions}

\subsection{Characterization of $n \mathrm{ZVI} / \mathrm{BC}$ Composite}

With the assistance of SEM, the morphologies of nZVI, BC, and nZVI/BC were clearly observed at a magnification of 10,000 (Figure 1). As seen in Figure 1a, the morphology of nZVI was spherical with a nanoscale particle size, and nZVI particles were easily stacked together due to the magnetic interaction and nano-material properties. The morphology of peanut shell BC was reticular, which showed a skeleton under SEM observation in Figure 1b. The BC structure was well-preserved during the pyrolysis under $350^{\circ} \mathrm{C}$, shown by how the branches of $\mathrm{BC}$ are neatly arranged and how each has enough space for nZVI adhesion. Because of the good dispersion of BC, nZVI was evenly distributed on the sticks of the peanut shells (Figure 1c). Therefore, BC made from peanut shells has a unique morphological structure, which could succeed in avoiding the aggregation of nZVI and might furthermore exhibit other good prospects. The EDS (Energy-disperse spectra) elemental mapping can identify the surface element composition of nZVI/BC. In Figure 1d, the spectrum of EDS depicts that the nanocomposite catalyst contains $\mathrm{C}, \mathrm{O}$, and $\mathrm{Fe}$. The characterizations above have visually explained the successful synthesis of the $\mathrm{nZVI} / \mathrm{BC}$ nanocomposite material. 

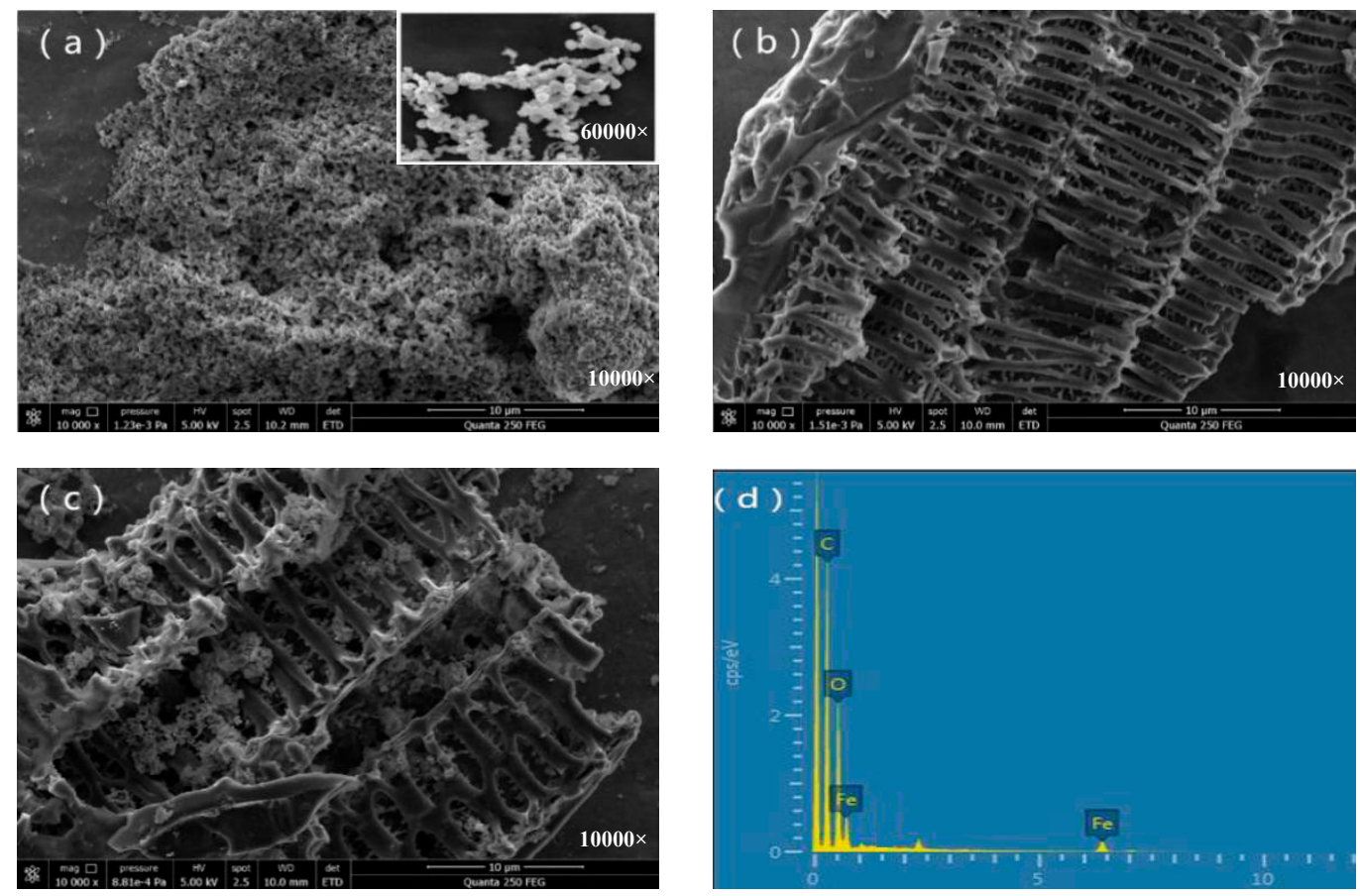

Figure 1. Scanning electron microscopy (SEM) images of nano zero-valent iron (nZVI) (a), peanut shell biochar (BC) (b), nZVI/peanut shell BC (c), and the EDS (Energy-disperse spectra) pattern of $\mathrm{nZVI} /$ peanut shell BC $(\mathbf{d})$.

The pore size of $\mathrm{nZVI} / \mathrm{BC}$ was mainly distributed within a range of $2 \sim 50 \mathrm{~nm}$, which proved the mesoporous structure of $\mathrm{nZVI} / \mathrm{BC}$ (Figure 2). The BET surface areas of these materials showed that $\mathrm{nZVI} / 2 \mathrm{BC}$ obtained the highest surface area because higher $\mathrm{BC}$ content in $\mathrm{nZVI} / \mathrm{BC}$ composite is beneficial to nZVI dispersion. However, the surface area of nZVI/3BC was decreased by further adding $\mathrm{BC}$ contents, owing to the increasing aggregation of $\mathrm{BC}$ sheets.

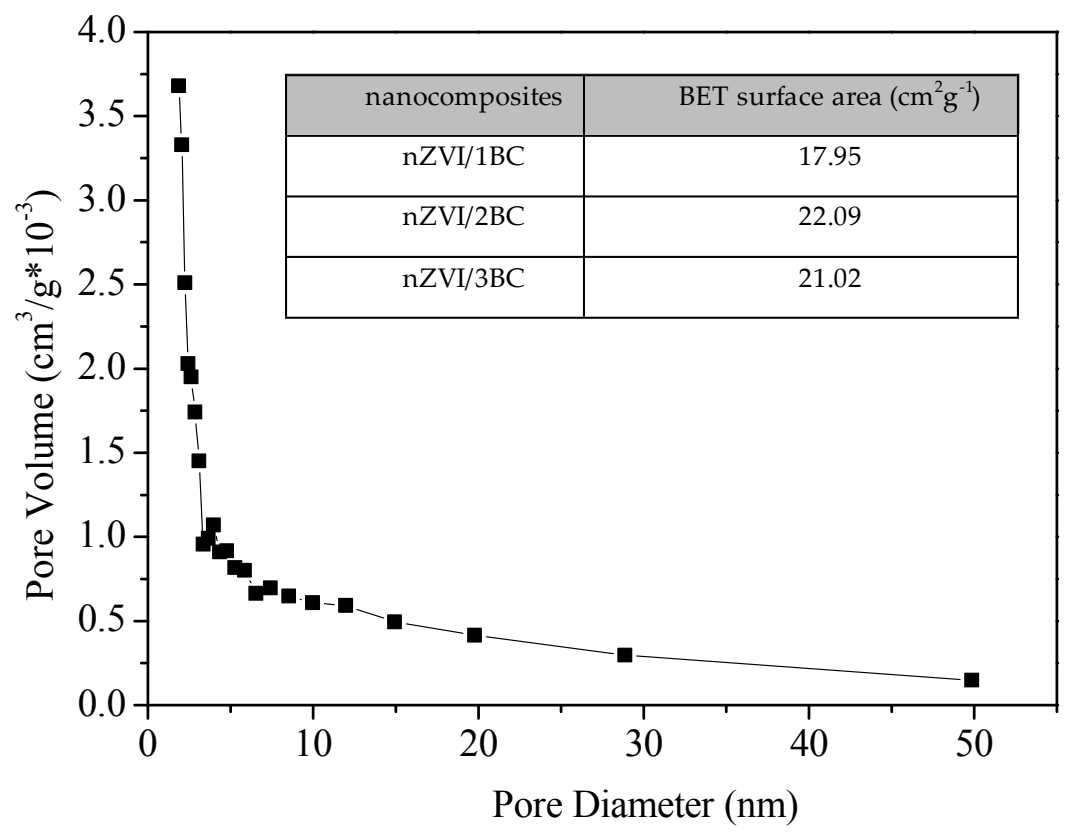

Figure 2. The pore size distribution of $\mathrm{nZVI} / \mathrm{BC}$, and the Brunauer-Emmett-Teller (BET) surface area (inset). 
The crystalline phases of the prepared samples were determined by powder XRD measurements. The XRD patterns of nZVI, BC, and nZVI/BC are depicted in Figure 3. The diffraction peaks of all samples are shown in the representative position. The peak at $2 \theta=45^{\circ}$ confirms the presence of $\alpha-\mathrm{Fe}$, which shows that nZVI was obviously synthesized by the liquid-phase reduction method. The representative peak at $2 \theta=20^{\circ}-25^{\circ}$ is ascribed to the graphite structure of BC [44]. After synthesis, the characteristics of $\mathrm{nZVI}$ and $\mathrm{BC}$ are reflected in the particular position of the nZVI/BC diffraction pattern.

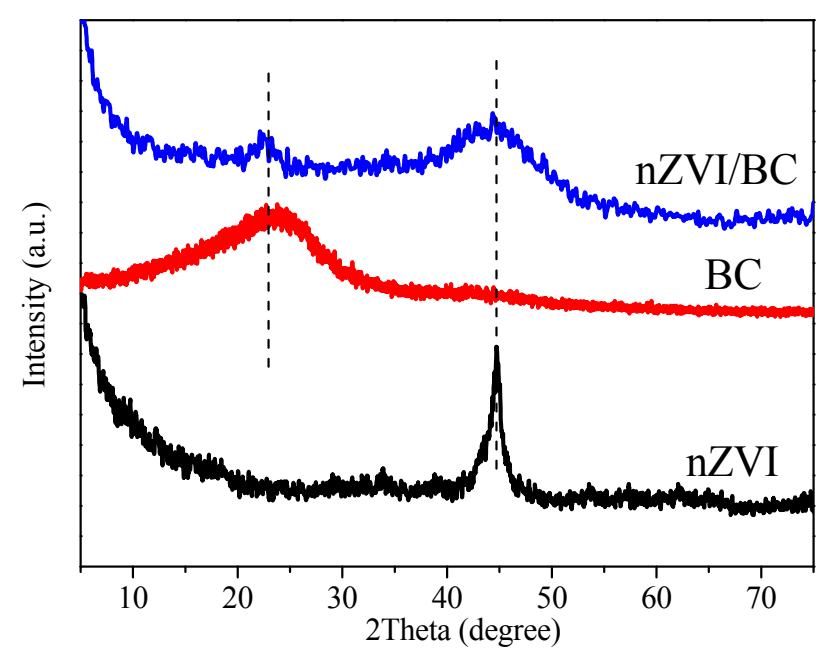

Figure 3. X-ray diffraction (XRD) patterns of nZVI, BC, and nZVI/BC.

FTIR spectra of BC and nZVI/BC are shown in Figure 4. The spectra of nZVI/BC and BC exhibit a broad band at $3434 \mathrm{~cm}^{-1}$, which is associated to $-\mathrm{OH}$ groups [47]. The band at $1600 \mathrm{~cm}^{-1}$ is associated with the carbonyl of the carboxylic group $(\mathrm{C}=\mathrm{O})[47,48]$. The weak peak at $2936 \mathrm{~cm}^{-1}$ and $1384 \mathrm{~cm}^{-1}$ can be assigned to the bending vibration of $\mathrm{C}-\mathrm{H}$ [49]. The bonding effects resulting from $\mathrm{nZVI}$ and $\mathrm{BC}$ might be represented by a peak at $650 \mathrm{~cm}^{-1}$ on behalf of Fe-O-H [50]. These characteristic peaks are again proof of the successful preparation of the composite material.

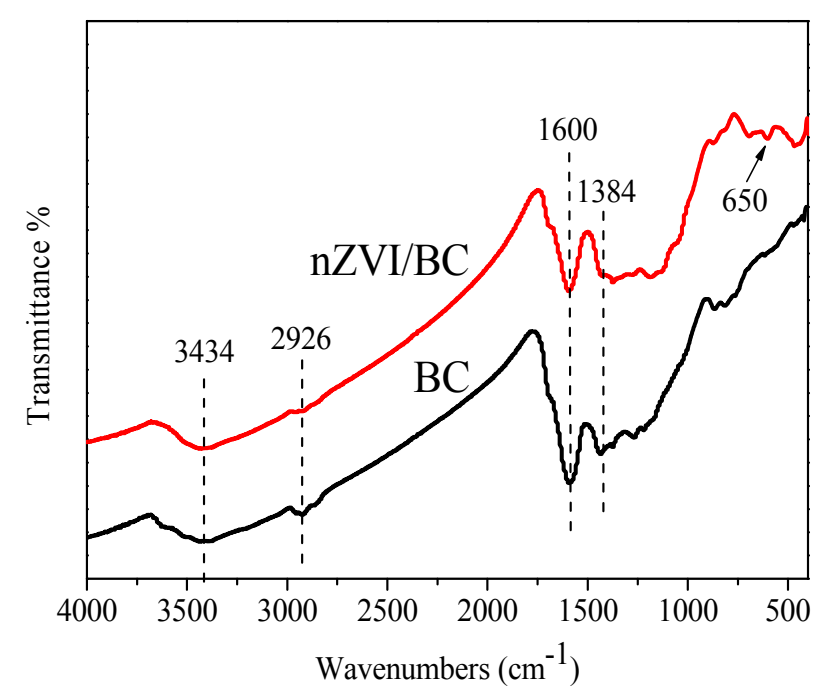

Figure 4. Fourier transform infrared spectroscopy (FT-IR) spectra of BC and nZVI/BC. 


\section{2. nZVI/BC Activation of PS for DTZ Removal}

\subsubsection{Adsorption}

Before the degradation experiment of DTZ, adsorption of the as-prepared material to the target compound was conducted. $\mathrm{BC}, \mathrm{nZVI} / 1 \mathrm{BC}, \mathrm{nZVI} / 2 \mathrm{BC}$, and $\mathrm{nZVI} / 3 \mathrm{BC}$ were used to investigate the effects of adsorption. The adsorption capacity of these materials are shown in Figure 5, where the adsorption removal of DTZ by various materials were only $~ 3.5 \%$ after $120 \mathrm{~min}$, which indicates that adsorption effect of these materials is very low. As can be seen in Figure 5, the adsorption removal rates have no significant difference from $60 \mathrm{~min}$ to $120 \mathrm{~min}$, with the rates being $\sim 3.3 \%$ to $\sim 3.5 \%$. When considering the time it takes to conduct the experiment, the degradation experiment can be performed after $60 \mathrm{~min}$ of adsorption.

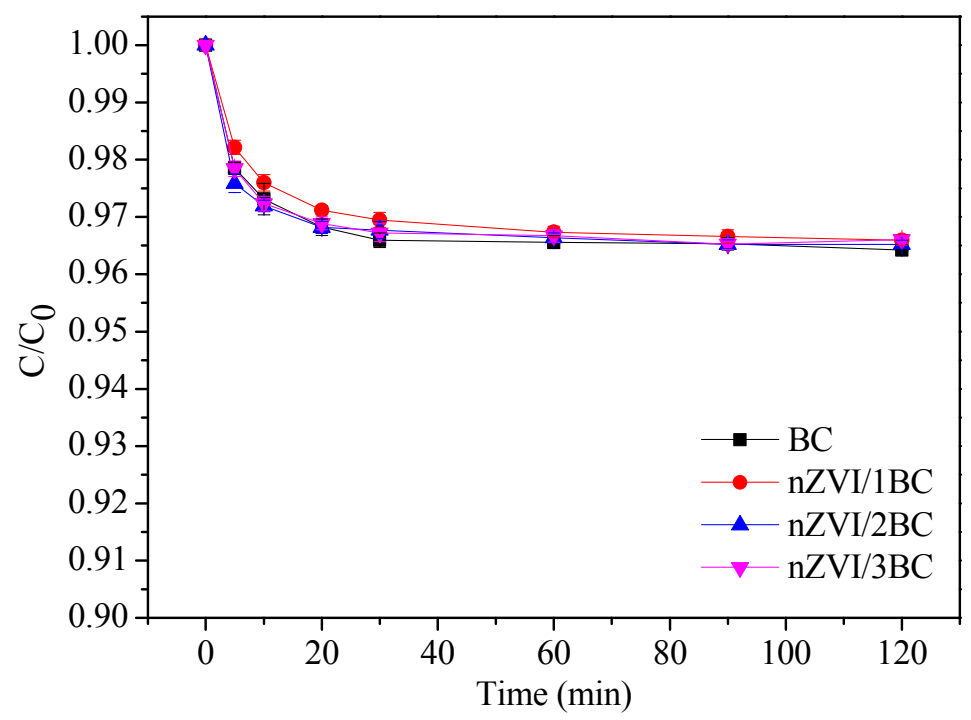

Figure 5. The adsorption of diatrizoate (DTZ) by BC, nZVI/1BC (mass ratio of $1: 1$ ), nZVI/2BC (mass ratio of 1:2), and $\mathrm{nZVI} / 3 \mathrm{BC}$ (mass ratio of 1:3).

\subsubsection{Degradation}

To highlight the catalytic effect of composite materials in removing DTZ, nZVI, BC, and nZVI/BC composites with different mass ratios (1:1-1:3) in the presence of PS were investigated for $120 \mathrm{~min}$ after being largely unaffected by adsorption $(60 \mathrm{~min})$. The entire experiment lasted $180 \mathrm{~min}$. Figure 6a shows that PS alone was the least effective $(\sim 6 \%)$ at DTZ removal. This is because PS has weak oxidation ability $\left(\mathrm{E}_{0}=2.01 \mathrm{~V}\right)$ due to its low activation and few sulfate radicals generated. The sample BC-PS exhibited better performance than PS alone, with the DTZ degradation rate being $14.7 \%$. This could be due to the fact that the PS was slightly activated by the function groups in the BC mentioned in the infrared characterization [50-52]. The ability of nZVI in activating PS was confirmed by its $45.8 \%$ DTZ removal rate. Meanwhile, the consumption of PS by nZVI-PS was $\sim 38 \%$ (Figure $6 \mathrm{~b}$ ), which demonstrated that activation by nZVI alone could not fully develop the potential of PS. Although there was no significant difference in the adsorption capacities of the three nanocomposites with various mass ratios, the ability to activate persulfate varied greatly. The DTZ degradation rates by PS activated with nZVI/1BC, nZVI/2BC, and nZVI/3BC were $84.3 \%, 91.5 \%$, and $73.6 \%$ respectively after deducting the quantity of adsorption. Meanwhile, the remaining PS concentration ratios were at $42.2 \%, 30.2 \%$, and $44.6 \%$, respectively. nZVI/2BC exhibited the best catalytic capability in the degradation of DTZ, and the utilization of PS was the highest. The removal of DTZ by nZVI/1BC was inferior to nZVI/2BC, which might be due to the fact that there was not enough $B C$ to disperse the large amount of nZVI. However, excessive $\mathrm{BC}$ may also have a negative impact on the generation of $\mathrm{SO}_{4}{ }^{--}$through reducing 
the contact between NZVI and PS, resulting from the aggregation of BC sheets [44,49]. Therefore, the $\mathrm{nZVI} / 2 \mathrm{BC}$ was identified to be the most effective composite material and was selected as the activation reagent for further study.
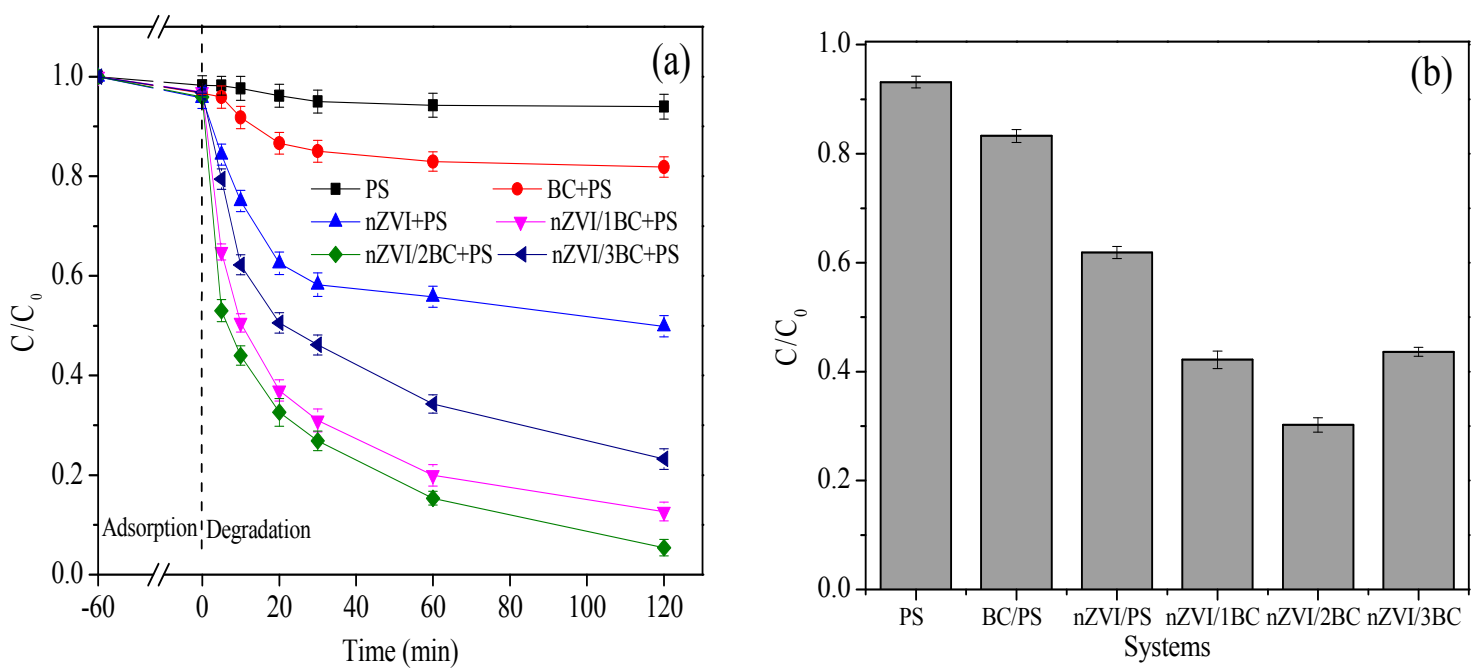

Figure 6. (a) The degradation of DTZ in different systems. (b) The residual of persulfate (PS) in different systems. $[\mathrm{DTZ}]=20 \mathrm{mg} \mathrm{L}^{-1}$; $[\mathrm{PS}]=25.0 \mathrm{mM}$; $[\mathrm{BC}]=0.30 \mathrm{~g} \mathrm{~L}^{-1} ;[\mathrm{nZVI}]=0.15 \mathrm{~g} \mathrm{~L}^{-1}$; $\mathrm{Temp}=25^{\circ} \mathrm{C}$; $\mathrm{pH}=7.0$.

\subsection{Effect of $n Z V I / 2 B C$ and PS Dosage}

Figure 7 shows the effect of nZVI/2BC and PS dosages on the degradation of DTZ. In Figure 7a, the DTZ removal rates ranges from $54.2 \%$ to $91.5 \%$ under dosages of $\mathrm{nZVI} / 2 \mathrm{BC}$ ranging from 0.15 to $0.45 \mathrm{~g} \mathrm{~L}^{-1}$ with $25 \mathrm{mM}$ PS. The trend shows that the degradation efficiency increases with the amount of nZVI/2BC being applied. Because the loaded nZVI is accompanied by an increase in the amount of composite materials, $\mathrm{Fe}^{2+}$ would be persistently released to activate PS to generate more $\mathrm{SO}_{4}{ }^{\bullet-}$, correspondingly. However, the degradation efficiency using $0.60 \mathrm{~g} \mathrm{~L}^{-1} \mathrm{nZVI} / 2 \mathrm{BC}$ is shown to decrease to $78.3 \%$, which may be due to how excessive $\mathrm{Fe}^{2+}$ can integrate with $\mathrm{SO}_{4}{ }^{\bullet-}$. Thus, some of $\mathrm{SO}_{4}{ }^{\bullet-}$ did not participate in the degradation of DTZ but reacted with $\mathrm{Fe}^{2+}$ as a scavenging reaction (Equation (1)).

$$
\mathrm{SO}_{4}{ }^{\bullet-}+\mathrm{Fe}^{2+} \rightarrow \mathrm{S}_{2} \mathrm{O}_{8}{ }^{2-}+\mathrm{Fe}^{3+}
$$

The effects of the different PS concentration levels $(5,15,25$, and $50 \mathrm{mM})$ with $0.45 \mathrm{~g} \mathrm{~L}^{-1} \mathrm{nZVI} / 2 \mathrm{BC}$ on the degradation of DTZ is shown in Figure $7 \mathrm{~b}$. The removal rates of DTZ in four groups were 59.6\%, $75.4 \%, 91.5 \%$, and $100 \%$, respectively. It can be seen that the higher the concentration of PS, the better the degradation of DTZ. In addition, DTZ degrades rapidly in the first $20 \mathrm{~min}$, and $50 \mathrm{mM}$ PS was able to fully degrade the DTZ activated by nZVI/2BC in $120 \mathrm{~min}$. With the increase in PS dosage, plenty of $\mathrm{SO}_{4}{ }^{\bullet-}$ were generated due to the intensive decomposition of PS, which enhanced the degradation of DTZ. 

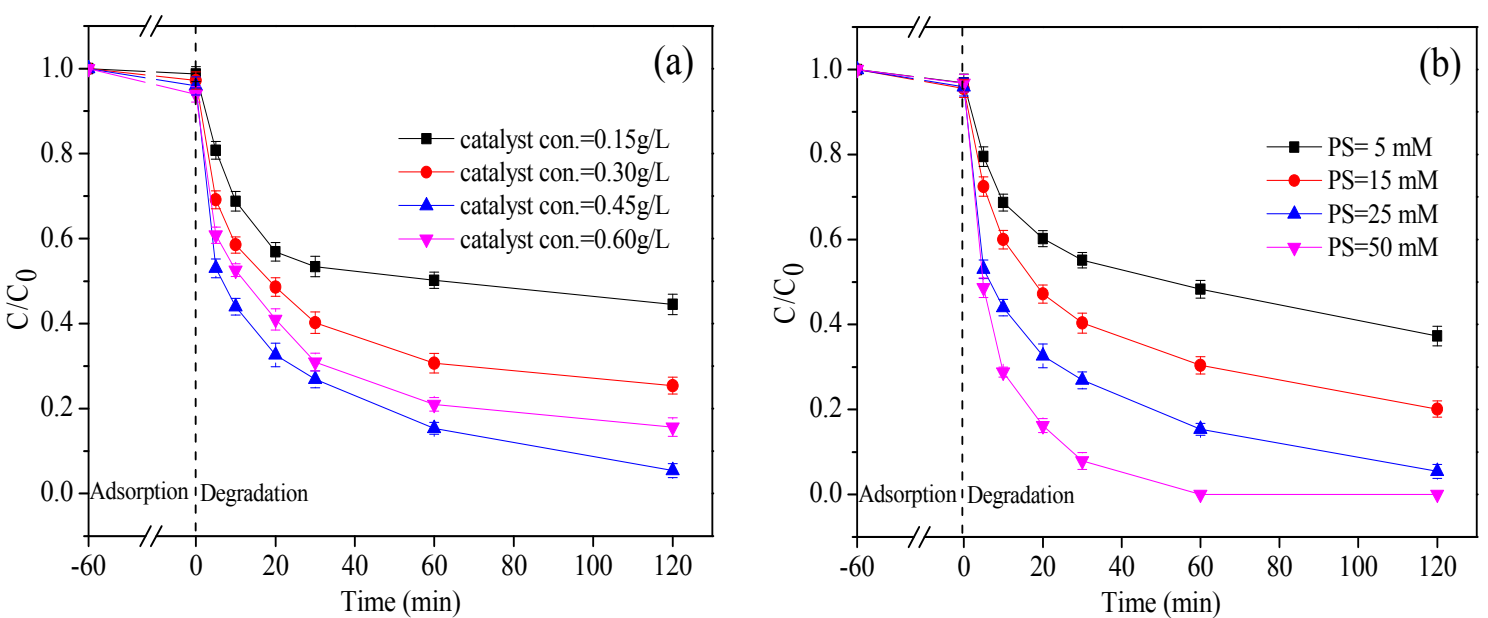

Figure 7. (a) Effect of nZVI/2BC dosages on the degradation of DTZ; (b) Effect of PS concentrations on the degradation of DTZ. [DTZ] $=20 \mathrm{mg} \mathrm{L}^{-1}$; Temp $=25^{\circ} \mathrm{C} ; \mathrm{pH}=7.0 ;$ [PS] $=25.0 \mathrm{mM}$ for (a) or $[\mathrm{nZVI} / 2 \mathrm{BC}]=0.45 \mathrm{~g} \mathrm{~L}^{-1}$ for $(\mathbf{b})$.

\subsection{Effect of Reaction Temperature and Solution $\mathrm{pH}$}

It was reported that heat could activate PS to release sulfate radicals by opening the $\mathrm{O}-\mathrm{O}$ bond $[53,54]$ (Equation (2)).

$$
\mathrm{S}_{2} \mathrm{O}_{8}^{2-}+\text { heat } \rightarrow 2 \mathrm{SO}_{4}^{\bullet-}
$$

In this study, the effect of the reaction temperature on the activation of PS with nZVI/2BC was studied. It can be seen from Figure 8 a that the low temperature significantly restricted the degradation efficiency of DTZ. More specifically, when the temperature was $15^{\circ} \mathrm{C}$, the degradation efficiency of DTZ was only $47.1 \%$ after $120 \mathrm{~min}$, and when the temperature was $25^{\circ} \mathrm{C}$, the degradation rate greatly increased to $\sim 92 \%$. It can thus be inferred that the degradation reaction is very sensitive to temperature, and is most affected between $15^{\circ} \mathrm{C}$ and $25^{\circ} \mathrm{C}$. When the nZVI/2BC-PS system performed at $45^{\circ} \mathrm{C}$, the removal rate of DTZ was nearly $100 \%$ in $30 \mathrm{~min}$. The results also imply that DTZ degradation follows the pseudo-first-order kinetic equation (Figure 8c). The fitting coefficients $R^{2}$ were over 0.99 , and DTZ reaction kinetics rate constants were equal to $0.0045,0.0218,0.0268$, and $0.1232 \mathrm{~min}^{-1}$ at 15,25 , 35 , and $45^{\circ} \mathrm{C}$, respectively (Table 1 ). According to the laws of thermodynamics and the experimental results, the reaction kinetics rate constant $k$ increased as the temperature increased, and both of them fit with the Arrhenius equation (Equation (3)).

$$
K=A \exp \left(\frac{-E a}{R T}\right)
$$

A straight linear correlation between $\ln K$ and $1 / T$ was achieved. The calculated $E a$ was approximately $9.07 \times 10^{3} \mathrm{~J} \mathrm{~mol}^{-1}$ within the range of $15-45{ }^{\circ} \mathrm{C}$, and the pre-exponential factor $A$ was $26.17 \mathrm{~min}^{-1}$, showing that the reaction was endothermal. 

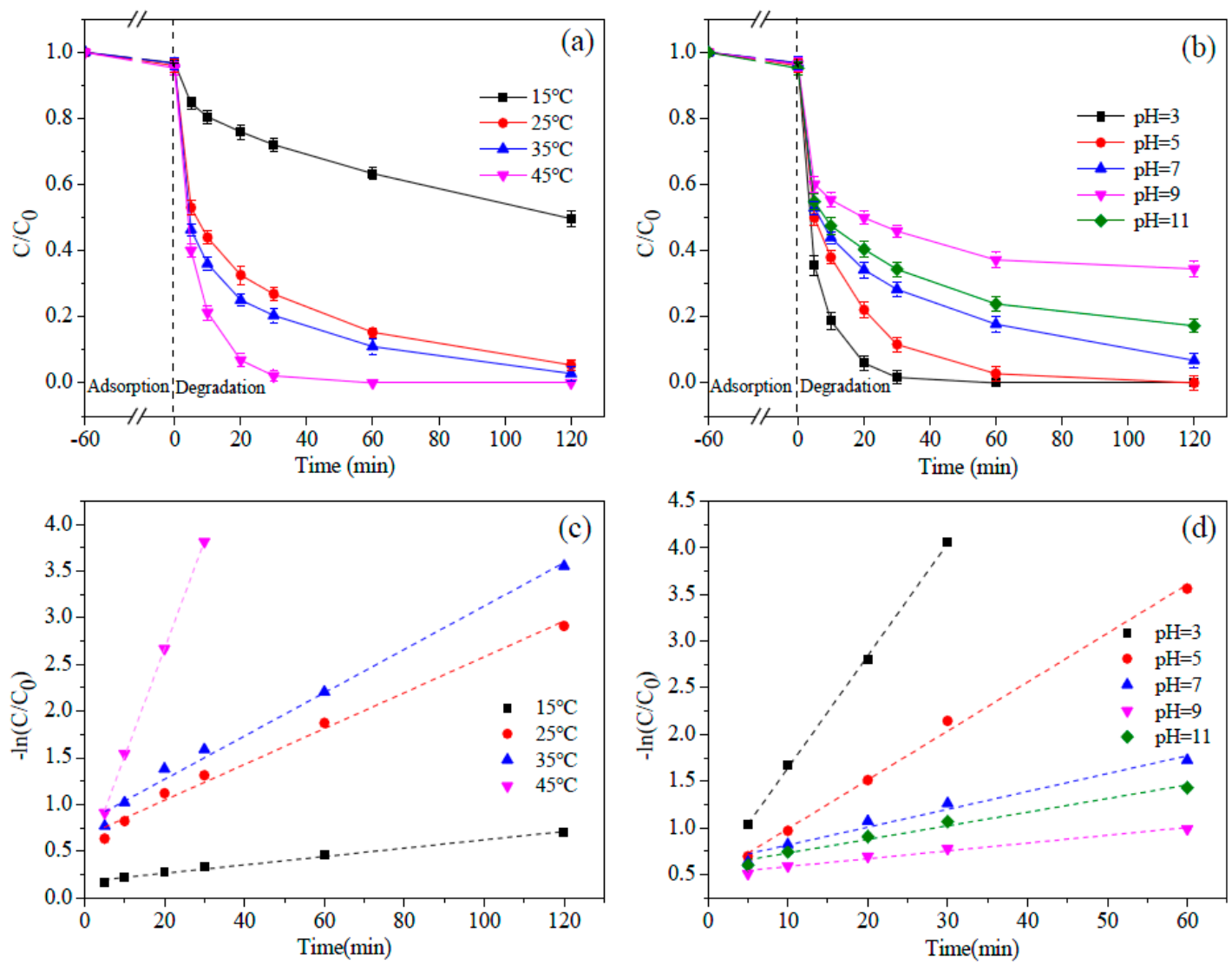

Figure 8. (a) Effect of temperature on the degradation of DTZ. [DTZ] $=20 \mathrm{mg} \mathrm{L}^{-1}$; [nZVI/2BC] $=$ $0.45 \mathrm{~g} \mathrm{~L}^{-1}$; [PS] $=25.0 \mathrm{mM} ; \mathrm{pH}=7.0$. (b) Effect of $\mathrm{pH}$ on the degradation of DTZ. (c) Corresponding kinetic curves of DTZ with different temperatures. (d) Corresponding kinetic curves of DTZ with different $\mathrm{pH}$ values $[\mathrm{DTZ}]=20 \mathrm{mg} \mathrm{L}^{-1} ;[\mathrm{nZVI} / 2 \mathrm{BC}]=0.45 \mathrm{~g} \mathrm{~L}^{-1} ;[\mathrm{PS}]=25.0 \mathrm{mM}$; Temp $=25^{\circ} \mathrm{C}$.

Table 1. The kinetic parameters of DTZ removal by different temperatures and $\mathrm{pH}$.

\begin{tabular}{ccccc}
\hline Factors & Gradient & Kinetic Equations & $\boldsymbol{R}^{\mathbf{2}}$ & $\boldsymbol{k} /\left(\mathbf{m i n}^{\mathbf{- 1}}\right)$ \\
\hline \multirow{4}{*}{ Temperature } & $15^{\circ} \mathrm{C}$ & $-\ln \left(C / C_{0}\right)=0.0045 \mathrm{t}+0.1745$ & 0.9912 & 0.0045 \\
& $25^{\circ} \mathrm{C}$ & $-\ln \left(C / C_{0}\right)=0.0192 \mathrm{t}+0.6622$ & 0.9903 & 0.0192 \\
& $35^{\circ} \mathrm{C}$ & $-\ln \left(C / C_{0}\right)=0.0232 \mathrm{t}+0.8061$ & 0.9912 & 0.0232 \\
& $45^{\circ} \mathrm{C}$ & $-\ln \left(C / C_{0}\right)=0.1154 \mathrm{t}+0.3617$ & 0.9997 & 0.1154 \\
\hline \multirow{2}{*}{$\mathrm{pH}$} & 3 & $-\ln \left(C / C_{0}\right)=0.1294 \mathrm{t}+0.2391$ & 0.9912 & 0.1294 \\
& 5 & $-\ln \left(C / C_{0}\right)=0.0523 \mathrm{t}+0.4676$ & 0.9970 & 0.0523 \\
& 7 & $-\ln \left(C / C_{0}\right)=0.0171 \mathrm{t}+0.6687$ & 0.9901 & 0.0171 \\
& 9 & $-\ln \left(C / C_{0}\right)=0.0084 \mathrm{t}+0.5021$ & 0.9808 & 0.0084 \\
& 11 & $-\ln \left(C / C_{0}\right)=0.0146 \mathrm{t}+0.5854$ & 0.9822 & 0.0146 \\
\hline
\end{tabular}

It is well-known that solution $\mathrm{pH}$ is one of the most important influencing factors which affect the degradation of DTZ by the nZVI/BC-PS system. The effect of solution $\mathrm{pH}$ on the degradation of DTZ was investigated. As shown in Figure 8b, the order of DTZ removal is pH $3.0>\mathrm{pH} 5.0$ $>\mathrm{pH} 7.0>\mathrm{pH} 11.0>\mathrm{pH}$ 9.0. The maximum removal was $100 \%$ at $\mathrm{pH} 3.0$, and the minimum removal rate was $61.8 \%$ at $\mathrm{pH} 9.0$. The degradation of DTZ increased as the solution $\mathrm{pH}$ decreased from 9.0 to 3.0. This tendency can be explained as follows (Equations (4) and (5)): Under acidic conditions, sulfate radicals are easily motivated because of acid catalysis [11,55], which is consistent with the previous study which found that acidic $\mathrm{pH}(\mathrm{pH} 3.0)$ favored the removal of nonylphenol and trichloroethylene $[44,49]$. Under basic conditions, some sulfate radicals can react with hydroxyl or 
$\mathrm{H}_{2} \mathrm{O}$. A small quantity of generated hydroxyl radicals had relatively shorter lifetimes compared to sulfate radicals, which had a serious impact on the degradation of organic pollutants.

$$
\begin{gathered}
\mathrm{S}_{2} \mathrm{O}_{8}{ }^{2-}+\mathrm{H}^{+} \rightarrow \mathrm{HS}_{2} \mathrm{O}_{8}{ }^{-} \\
\mathrm{HS}_{2} \mathrm{O}_{8}{ }^{-} \rightarrow \mathrm{H}^{+}+\mathrm{SO}_{4}{ }^{2-}+\mathrm{SO}_{4}{ }^{\bullet-} \\
\mathrm{SO}_{4}{ }^{\bullet-}+\mathrm{OH}^{-} \rightarrow \mathrm{HO}^{\bullet}+\mathrm{SO}_{4}{ }^{2-}
\end{gathered}
$$

However, the degradation rate of DTZ was $78.6 \%$ at $\mathrm{pH} 11$, which is higher than that $\mathrm{pH}$ 9.0. Under extremely alkaline conditions, the sulfate radical produced can catch an electron from hydroxyl, forming a predominate hydroxyl radical that also has high redox potential [56-58] (Equation (6)). Basic activation caused by the solution of $\mathrm{pH} 11$ was applicable to the degradation of DTZ. By calculating the kinetic equation, the highest DTZ degradation rate of $\mathrm{pH} 3\left(0.1294 \mathrm{~min}^{-1}\right)$ was $\sim 2.5, \sim 7.5, \sim 15.5$, and $\sim 8.9$ times faster than those of $\mathrm{pH} 5\left(0.0523 \mathrm{~min}^{-1}\right), \mathrm{pH} 7\left(0.0171 \mathrm{~min}^{-1}\right), \mathrm{pH} 9$ $\left(0.0084 \mathrm{~min}^{-1}\right)$, and $\mathrm{pH} 11\left(0.0146 \mathrm{~min}^{-1}\right)$. Therefore, the nZVI/2BC-PS system can effectively degrade refractory organic pollutants when under an acidic condition followed by a strong alkaline condition.

\subsection{DTZ Mineralization}

It is necessary to analyze the concentrations of TOC in each aqueous solution, since the purpose of the DTZ degradation was not only the degradation itself but also to obtain its mineralization. In Figure 9, the trend line of the mineralization is roughly similar to the removal rate of DTZ, and the ultimate mineralization of DTZ is $61 \%$ after $120 \mathrm{~min}$, which is reasonable and shows that decomposition was not fully completed. The intermediate products were produced and required a longer time to mineralize them thoroughly.

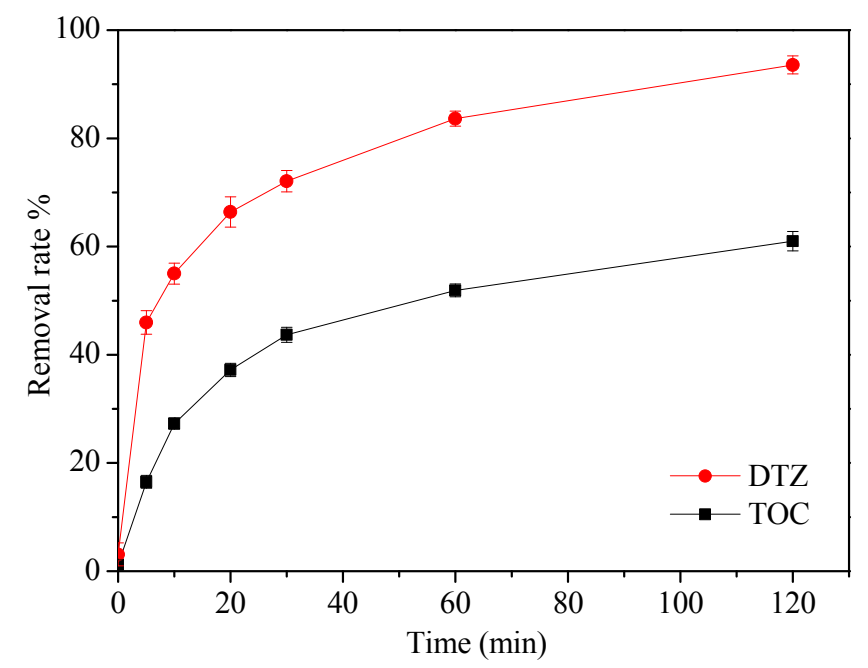

Figure 9. The removal rate of TOC (Total organic carbon) and DTZ. [DTZ] $=20 \mathrm{mg} \mathrm{L}^{-1}$; [nZVI/2BC] $=$ $\left.0.45 \mathrm{~g} \mathrm{~L}^{-1} ; \mathrm{PS}\right]=25.0 \mathrm{mM} ; \mathrm{Temp}=25^{\circ} \mathrm{C} ; \mathrm{pH}=7.0$.

\subsection{Activation Mechanism}

The activation mechanism of PS is generally described in Figure 10. Peanut shell BC played a very important role in the degradation of DTZ. The degradation efficiency of DTZ (14.7\%) in the BC-PS system was higher than the DTZ removal rate $(\sim 6 \%)$ with PS alone. It showed that peanut shell $\mathrm{BC}$ was able to activate PS to release $\mathrm{SO}_{4}{ }^{-}$based on the abundant oxygen functional groups (containing $\mathrm{BC}-\mathrm{COOH}$ and $\mathrm{BC}-\mathrm{OH}$ ) on the $\mathrm{BC}$ surface (Equations (7) and (8)) [59,60]. In addition, the well-arranged mesh structure of peanut shell BC provided enough binding sites for nZVI, which was beneficial in dispersing the nZVI magnetic particles for full activation. 


$$
\begin{aligned}
\mathrm{BC}-\mathrm{OOH}+\mathrm{S}_{2} \mathrm{O}_{8}{ }^{2-} & \rightarrow \mathrm{BC}-\mathrm{OO}{ }^{\bullet}+\mathrm{SO}_{4}{ }^{\bullet-}+\mathrm{HSO}_{4}{ }^{-} \\
\mathrm{BC}-\mathrm{OH}+\mathrm{S}_{2} \mathrm{O}_{8}{ }^{2-} & \rightarrow \mathrm{BC}-\mathrm{O}^{\bullet}+\mathrm{SO}_{4}{ }^{\bullet-}+\mathrm{HSO}_{4}{ }^{-}
\end{aligned}
$$

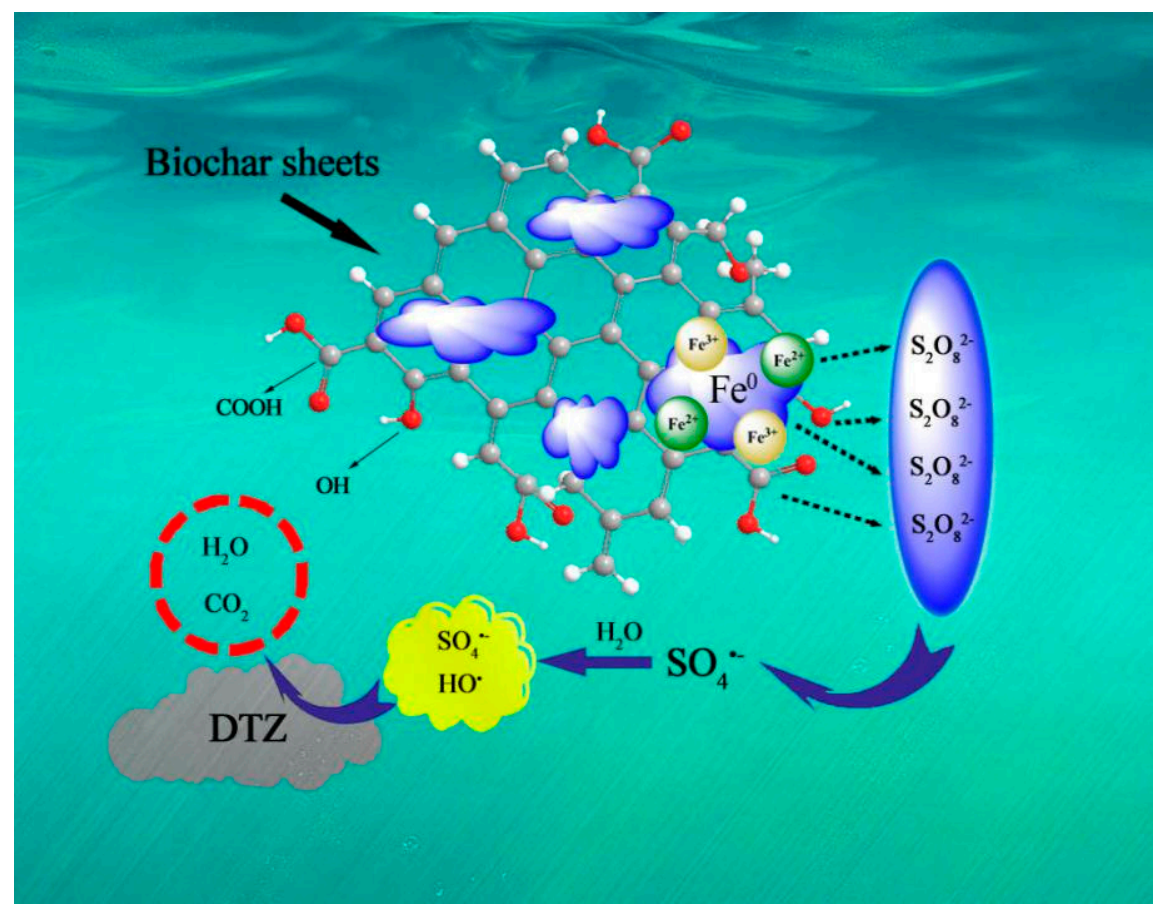

Figure 10. The mechanism of $\mathrm{nZVI} / \mathrm{BC}$ activating PS for the degradation of DTZ. [DTZ] $=20 \mathrm{mg} \mathrm{L}^{-1}$; $[\mathrm{nZVI} / 2 \mathrm{BC}]=0.45 \mathrm{~g} \mathrm{~L}^{-1} ;[\mathrm{PS}]=25.0 \mathrm{mM} ; \mathrm{Temp}=25^{\circ} \mathrm{C} ; \mathrm{pH}=7.0$.

Figure 11 shows the concentration of dissolved iron and the conversion among $\mathrm{Fe}^{0}, \mathrm{Fe}^{2+}$, and $\mathrm{Fe}^{3+}$. The concentrations of $\mathrm{Fe}^{2+}$ and $\mathrm{Fe}^{3+}$ increases in the first five minutes, and the concentration of $\mathrm{Fe}^{2+}$ slowly declines after reaching the peak around $10 \mathrm{~min}$, after which the concentration of $\mathrm{Fe}^{3+}$ maintains a slow rise until it levels off. After 120 mins of reaction time, the concentrations of $\mathrm{Fe}^{2+}$ and $\mathrm{Fe}^{3+}$ were $2.93 \mathrm{mg} \mathrm{L}^{-1}$ and $7.02 \mathrm{mg} \mathrm{L}^{-1}$, respectively. The results indicate that a part of nZVI was transformed into dissolved iron in the presence of $\mathrm{PS}^{-\mathrm{Fe}^{0}}$ activated $\mathrm{PS}$ to form $\mathrm{SO}_{4}{ }^{\bullet-}, \mathrm{HO}^{\bullet}$, and $\mathrm{Fe}^{2+}$ in the aqueous solutions (Equations (9)-(11)). Meanwhile, the formed $\mathrm{Fe}^{2+}$ could also react with $\mathrm{S}_{2} \mathrm{O}_{8}{ }^{2-}$ to generate $\mathrm{SO}_{4}{ }^{\bullet-}$ and $\mathrm{Fe}^{3+}$ (Equation (11). The excessive $\mathrm{SO}_{4}{ }^{\bullet-}$ might react with $\mathrm{Fe}^{2+}$ to form $\mathrm{Fe}^{3+}$ (Equation (1)). Therefore, the concentration of $\mathrm{Fe}^{2+}$ increased first, then went down to equilibrium, and finally, the concentration of $\mathrm{Fe}^{3+}$ was higher than $\mathrm{Fe}^{2+}$.

$$
\begin{aligned}
\mathrm{Fe}^{0}+2 \mathrm{~S}_{2} \mathrm{O}_{8}{ }^{2-} & \rightarrow \mathrm{Fe}^{2+}+2 \mathrm{SO}_{4}{ }^{2-}+2 \mathrm{SO}_{4}{ }^{\bullet-} \\
\mathrm{Fe}^{0}+\mathrm{S}_{2} \mathrm{O}_{8}{ }^{2-}+2 \mathrm{H}_{2} \mathrm{O} & \rightarrow 2 \mathrm{SO}_{4}{ }^{2-}+\mathrm{Fe}^{2+}+2 \mathrm{HO}^{\bullet}+2 \mathrm{H}^{+} \\
\mathrm{Fe}^{2+}+\mathrm{S}_{2} \mathrm{O}_{8}{ }^{2-} & \rightarrow \mathrm{Fe}^{3+}+\mathrm{SO}_{4}{ }^{2-}+\mathrm{SO}_{4}{ }^{\bullet-}
\end{aligned}
$$




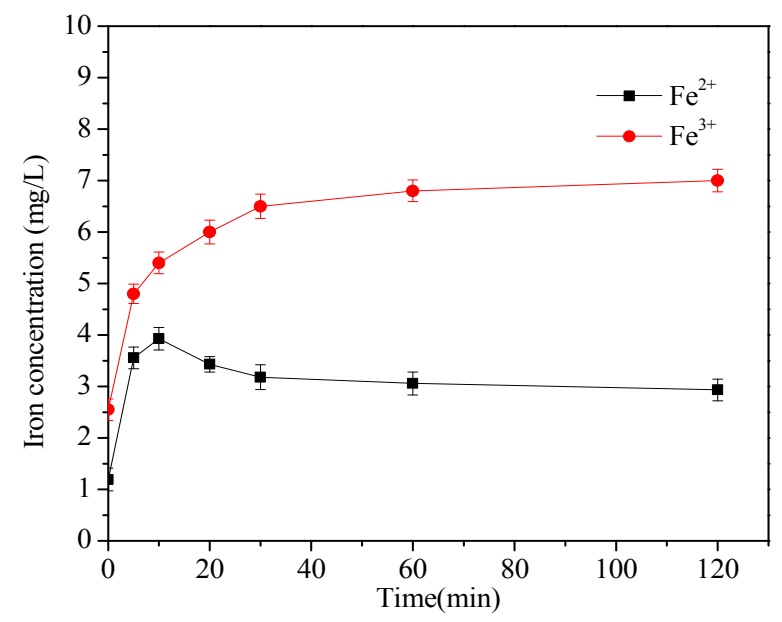

Figure 11. Concentration of $\mathrm{Fe}^{2+}$ and $\mathrm{Fe}^{3+}$ in the nZVI/2BC-PS system. [DTZ] $=20 \mathrm{mg} \mathrm{L}^{-1}$; [nZVI/2BC] $=0.45 \mathrm{~g} \mathrm{~L}^{-1} ;$ PS] $=25.0 \mathrm{mM} ; \mathrm{Temp}=25^{\circ} \mathrm{C} ; \mathrm{pH}=7.0$.

In order to figure out the radical species responsible for DTZ oxidation, sulfate radical and hydroxyl radical were investigated in comparative experiments at different $\mathrm{pH}$ values at $25{ }^{\circ} \mathrm{C}$. Tert-butyl alcohol (TBA) and ethanol $(\mathrm{EtOH})$ were the probe reagents used to examine the main radical species for the degradation of DTZ, as they had different quenching functions. The quenching effects of TBA to $\mathrm{HO}^{\bullet}$ are stronger than that of $\mathrm{SO}_{4}{ }^{\bullet-}\left(\mathrm{K}_{\mathrm{SO}}{ }^{\bullet-}=4.0-9.1 \times 10^{5} \mathrm{M}^{-1} \mathrm{~s}^{-1}, \mathrm{~K}_{\mathrm{HO}}{ }^{\bullet}=\right.$ 3.8-7.6 $\times 10^{8} \mathrm{M}^{-1} \mathrm{~s}^{-1}$ ). Both $\mathrm{SO}_{4}{ }^{-}-$and $\mathrm{HO}^{\bullet}$ can be effectively quenched by $\mathrm{EtOH}$ and the reaction rate constants of EtOH with $\mathrm{SO}_{4}{ }^{\bullet-}$ and $\mathrm{HO}^{\bullet}$ are $1.6-7.7 \times 10^{7} \mathrm{M}^{-1} \mathrm{~s}^{-1}$ and $1.2-2.8 \times 10^{9} \mathrm{M}^{-1} \mathrm{~s}^{-1}$, respectively [44,61]. Therefore, $0.1 \mathrm{M}$ TBA and $0.1 \mathrm{M} \mathrm{EtOH}$ were taken into the DTZ degradation system to determine the main radical species. The differences in degradation with or without the quenching reagent can be seen clearly in Figure 12.

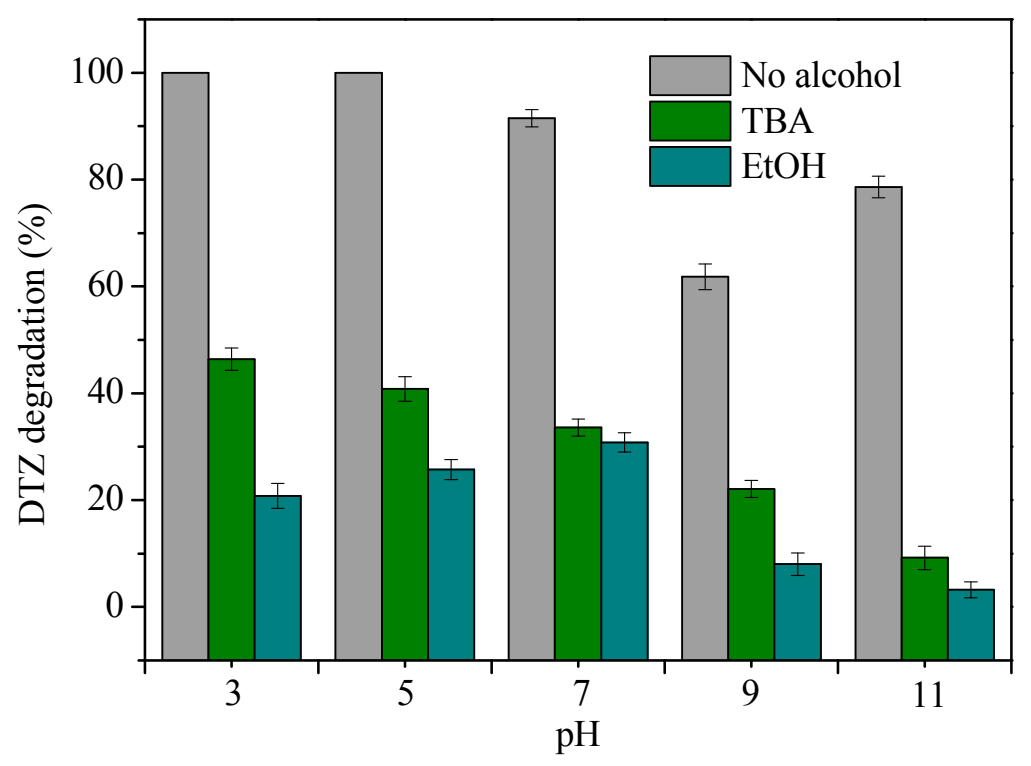

Figure 12. Effects of tert-butyl alcohol (TBA) and ethanol (EtOH) on the degradation of DTZ. [DTZ] = $20 \mathrm{mg} \mathrm{L}^{-1} ;[\mathrm{nZVI} / 2 \mathrm{BC}]=0.45 \mathrm{~g} \mathrm{~L}^{-1} ;[\mathrm{PS}]=25.0 \mathrm{mM} ; \mathrm{Temp}=25^{\circ} \mathrm{C} ; \mathrm{pH}=7.0$.

When $\mathrm{pH}$ ranges from 3.0 to 7.0, the blank sample exhibits favorable degradation. However, the degradation process was significantly inhibited, with removal efficiency decreasing from $100 \%$ to $46.4 \%$ and $100 \%$ to $20.8 \%$ by adding $\mathrm{TBA}$ and $\mathrm{EtOH}$ at $\mathrm{pH} 3.0$, respectively. The inhibition from 
EtOH was stronger than TBA, indicating that $\mathrm{SO}_{4}{ }^{\bullet-}$ played a dominant role at acidic and neutral conditions. When the $\mathrm{pH}$ value was around 11.0, the degradation of DTZ was $9.2 \%$ for TBA-quenching and $3.2 \%$ for EtOH-quenching, respectively. Both groups were significantly inhibited, especially for the TBA-quenching sample, which implies the main radicals in alkaline solution were $\mathrm{HO}^{\bullet}$. The quenching experiments and the above discussion for influencing factors fully demonstrate that $\mathrm{pH}$ plays a very important role on the degradation of DTZ by the nZVI/BC-PS system.

\subsection{The Stability of the $n Z V I / B C$}

Compared to simply adding nZVI, nZVI/BC was easier to collect after the experiment and could be recycled multiple times by peanut shell $\mathrm{BC}$ adhesion. As can be seen from the histogram (Figure 13), the five degradation rates of DTZ were $91.5 \%, 86.5 \%, 82.2 \%, 77.2 \%$, and $75.3 \%$, in turn. As the recycle increased, the degradation of DTZ decreased slowly. The degradation rate reduction might owe to: (1) The adsorption of DTZ on composite materials inhibiting the activation of PS by the catalyst; (2) $\mathrm{Fe}^{2+}$ running away led to the decrease of binding sites on the nZVI/2BC surface; (3) nZVI loaded on BC might have come off due to multiple flushing. Nevertheless, the nZVI/BC-PS can still degrade $77.3 \%$ of DTZ at the fifth run, which shows its potential in applicability.

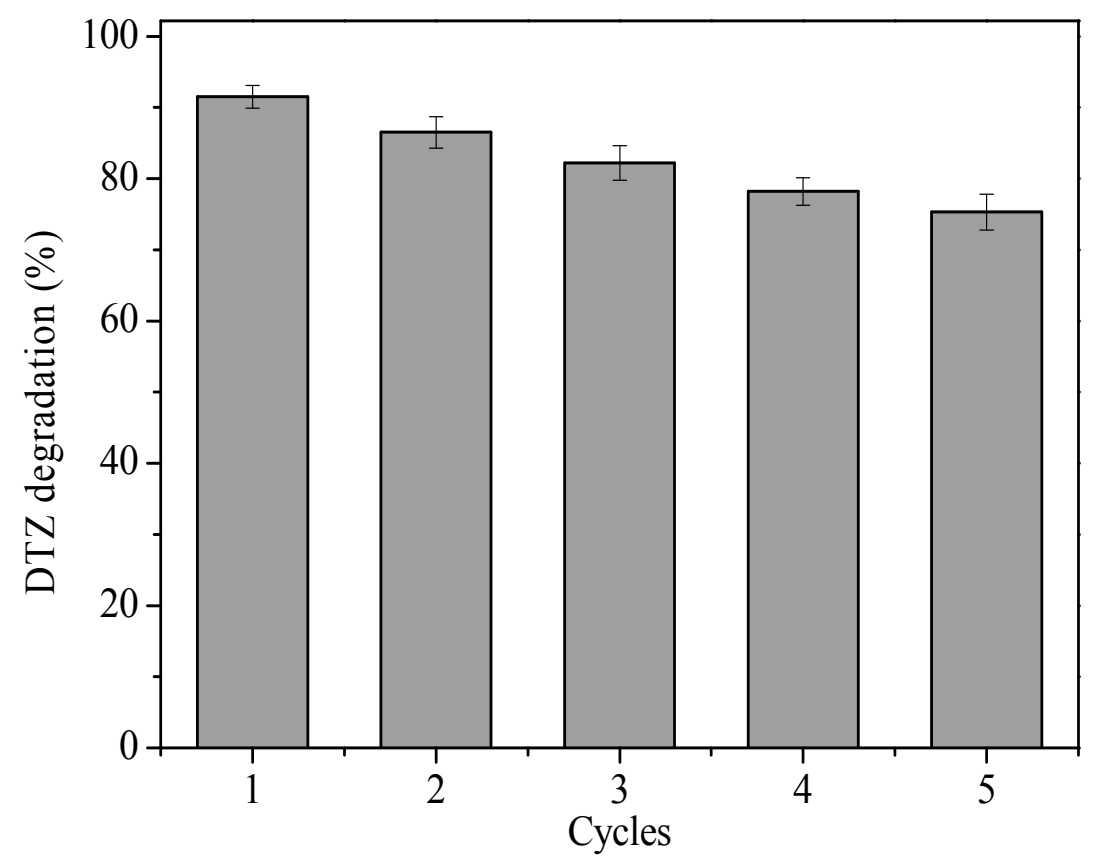

Figure 13. Reusability investigation of $\mathrm{nZVI} / 2 \mathrm{BC}$ composite materials for DTZ degradation. $[\mathrm{DTZ}]=20 \mathrm{mg} \mathrm{L}^{-1} ;[\mathrm{PS}]=25.0 \mathrm{mM} ;[\mathrm{nZVI} / 2 \mathrm{BC}]=0.45 \mathrm{~g} \mathrm{~L}^{-1} ; \mathrm{Temp}=25^{\circ} \mathrm{C} ; \mathrm{pH}=7.0$.

\section{Conclusions}

nZVI/BC (peanut shell) nanocomposite activating PS exhibited good efficiency for the degradation of DTZ. The results demonstrated that: (1) nZVI/2BC is an efficient nanocomposite, where the DTZ removal rate in the experiment ( $\mathrm{pH} 7$ ) was $94.6 \%$ (91.5\% degradation and $3.1 \%$ adsorption), and the DTZ removal rate in the optimized experiment ( $\mathrm{pH} 3.0$ ) was nearly $100 \%$. (2) The degradation efficiency of DTZ was affected by the dosage of nZVI/BC and PS, reaction temperature, and solution pH. (3) nZVI on the surface of peanut shell BC enhanced the redox effect between $\mathrm{Fe}^{2+}$ and $\mathrm{Fe}^{3+}$, which promoted the generation of $\mathrm{SO}_{4}{ }^{\bullet-}$. (4) Free radical quenching experiments revealed that both $\mathrm{SO}_{4}{ }^{\bullet-}$ and $\mathrm{HO}^{\bullet}$ were responsible for the degradation of DTZ. (5) Nanocomposite nZVI/BC prepared by peanut shell was recycled five times and considered to be an efficient catalyst of PS for the treatment of refractory organic contaminants. 
Author Contributions: Conceptualization, J.X., S.Y., H.H. and X.Z. (Xinhua Zhan); Formal analysis, J.X.; Investigation, J.X., X.Z. (Xueliang Zhang) and Y.D.; Writing-original draft, J.X.; Writing—review \& editing, C.S.; Supervision, Y.L.; Data curation, Q.L. and Y.Z.

Funding: This research was funded by the Major Science and Technology Program for Water Pollution Control and Treatment of China: No. 2017ZX07202004 and 2015ZX07204-007; National Natural Science Foundation of China: Nos. 51578279 and 21777067; Prospective Project on Integration of Industry, Education and Research of Jiangsu Province: BY2016116.

Conflicts of Interest: The authors declare no conflict of interest.

\section{References}

1. Ahmed, M.B.; Zhou, J.L.; Ngo, H.H.; Guo, W.S.; Thomaidis, N.S.; Xu, J. Progress in the biological and chemical treatment technologies for emerging contaminant removal from wastewater: A critical review. J. Hazard. Mater. 2017, 323, 274-298. [CrossRef] [PubMed]

2. Pantelaki, I.; Voutsa, D. Formation of iodinated THMs during chlorination of water and wastewater in the presence of different iodine sources. Sci. Total Environ. 2018, 613, 389-397. [CrossRef] [PubMed]

3. Ens, W.; Senner, F.; Gygax, B.; Schlotterbeck, G. Development, validation, and application of a novel LC-MS/MS trace analysis method for the simultaneous quantification of seven iodinated X-ray contrast media and three artificial sweeteners in surface, ground, and drinking water. Anal. Bioanal. Chem. 2014, 406, 2789-2798. [CrossRef] [PubMed]

4. Archer, E.; Petrie, B.; Kasprzyk-Hordern, B.; Wolfaardt, G.M. The fate of pharmaceuticals and personal care products (PPCPs), endocrine disrupting contaminants (EDCs), metabolites and illicit drugs in a WWTW and environmental waters. Chemosphere 2017, 174, 437-446. [CrossRef] [PubMed]

5. Seitz, W.; Weber, W.H.; Jiang, J.Q.; Lloyd, B.J.; Maier, M.; Maier, D.; Schulz, W. Monitoring of iodinated X-ray contrast media in surface water. Chemosphere 2006, 64, 1318-1324. [CrossRef] [PubMed]

6. Xu, Z.F.; Li, X.; Hu, X.L.; Ying, D.Q. Distribution and relevance of iodinated X-ray contrast media and iodinated trihalomethanes in an aquatic environment. Chemosphere 2017, 184, 253-260. [CrossRef] [PubMed]

7. Polo, A.M.S.; López-Peñalver, J.J.; Sánchez-Polo, M.; Rivera-Utrilla, J.; Velo-Gala, I.; Salazar-Rabago, J.J. Oxidation of diatrizoate in aqueous phase by advanced oxidation processes based on solar radiation. J. Photochem. Photobiol. A Chem. 2016, 319, 87-95. [CrossRef]

8. Meng, L.J.; Yang, S.G.; Sun, C.; He, H.; Xian, Q.M.; Li, S.Y.; Wang, G.X.; Zhang, L.M.; Jiang, D. A novel method for photo-oxidative degradation of diatrizoate in water via electromagnetic induction electrodeless lamp. J. Hazard. Mater. 2017, 2337, 34-46. [CrossRef] [PubMed]

9. Gale, M.E.; Robbins, A.H.; Hamburger, R.J.; Widrich, W.C. Renal toxicity of contrast agents: Iopamidol, iothalamate, and diatrizoate. Am. J. Roentgenol. 1984, 142, 333-335. [CrossRef] [PubMed]

10. Pfannenstiel, P.; Luhrbraun, A. Application of iodine-containing X-ray contrast media and thyroid-function. Med. Welt 1993, 44, 337-340.

11. Zhou, D.N.; Zhang, H.; Chen, L. Sulfur-replaced Fenton systems: Can sulfate radical substitute hydroxyl radical for advanced oxidation technologies? J. Chem. Technol. Biotechnol. 2015, 5, 775-779. [CrossRef]

12. Matzek, L.W.; Carter, K.E. Activated persulfate for organic chemical degradation: A review. Chemosphere 2016, 151, 178-188. [CrossRef] [PubMed]

13. Boczkaj, G.; Fernandes, A. Wastewater treatment by means of advanced oxidation processes at basic $\mathrm{pH}$ conditions: A review. Chem. Eng. J. 2017, 320, 608-633. [CrossRef]

14. Liang, C.J.; Bruell, C.J.; Marley, M.C.; Sperry, K.L. Persulfate oxidation for in situ remediation of TCE. I. Activated by ferrous ion with and without a persulfate-thiosulfate redox couple. Chemosphere 2004, 55, 1213-1223. [CrossRef] [PubMed]

15. Oh, S.Y.; Kang, S.G.; Chiu, P.C. Degradation of 2,4-dinitrotoluene by persulfate activated with zero-valent iron. Sci. Total Environ. 2010, 408, 3464-3468. [CrossRef] [PubMed]

16. Oh, S.Y.; Kang, S.G.; Kim, D.W.; Chiu, P.C. Degradation of 2,4-dinitrotoluene by persulfate activated with iron sulfides. Chem. Eng. J. 2011, 172, 641-646. [CrossRef]

17. Hussain, I.; Zhang, Y.Q.; Huang, S.B.; Du, X.Z. Degradation of $p$-chloroaniline by persulfate activated with zero-valent iron. Chem. Eng. J. 2012, 203, 269-276. [CrossRef]

18. Wang, X.; Wang, L.G.; Li, J.B.; Qiu, J.J.; Cai, C.; Zhang, H. Degradation of Acid Orange 7 by persulfate activated with zero valent iron in the presence of ultrasonic irradiation. Sep. Purif. Technol. 2014, 122, 41-46. [CrossRef] 
19. Liang, C.J.; Lai, M.C. Trichloroethylene degradation by zero valent iron activated persulfate oxidation. Environ. Eng. Sci. 2008, 25, 1071-1078. [CrossRef]

20. Wang, Y.; Chen, S.Y.; Yang, X.; Huang, X.F.; Yang, Y.H.; He, E.K.; Wang, S.Q.; Qiu, R.L. Degradation of 2,2',4,4'-tetrabromodiphenyl ether (BDE-47) by a nano zerovalent iron-activated persulfate process: The effect of metal ions. Chem. Eng. J. 2017, 317, 613-622. [CrossRef]

21. Phenrat, T.; Saleh, N.; Sirk, K.; Tilton, R.D.; Lowry, G.V. Aggregation and sedimentation of aqueous nanoscale zerovalent iron dispersions. Environ. Sci. Technol. 2007, 41, 284-290. [CrossRef] [PubMed]

22. Zhang, P.; Hou, D.Y.; O'Connor, D.; Li, X.R.; Pehkonen, S.O.; Varma, R.S.; Wang, X. Green and Size-Specific Synthesis of Stable Fe-Cu Oxides as Earth-Abundant Adsorbents for Malachite Green Removal. ACS Sustain. Chem. Eng. 2018, 53, 9229-9236. [CrossRef] [PubMed]

23. Zhang, P.; Lo, I.; O'Connor, D.; Pehkonen, S.; Cheng, H.F.; Hou, D.Y. High efficiency removal of methylene blue using SDS surface-modified $\mathrm{ZnFe}_{2} \mathrm{O}_{4}$ nanoparticles. J. Colloid Interface Sci. 2017, 508, 39-48. [CrossRef] [PubMed]

24. Park, H.; Park, Y.M.; Yoo, K.M.; Lee, S.H. Reduction of nitrate by resin-supported nanoscale zero-valent iron. Water Sci. Technol. 2009, 59, 2153-2157. [CrossRef] [PubMed]

25. Mackenzie, K.; Bleyl, S.; Georgi, A.; Kopinke, F.D. Carbo-Iron-An Fe/AC composite-As alternative to nano-iron for groundwater treatment. Water Res. 2012, 46, 3817-3826. [CrossRef] [PubMed]

26. Fukuchi, S.; Nishimoto, R.; Fukushima, M.; Zhu, Q.Q. Effects of reducing agents on the degradation of 2,4,6-tribromophenol in a heterogeneous Fenton-like system with an iron-loaded natural zeolite. Appl. Catal. B Environ. 2014, 147, 411-419. [CrossRef]

27. Kumar, S.; Singh, A.K.; Dasmahapatra, A.K.; Mandal, T.K.; Bandyopadhyay, D. Graphene based multifunctional superbots. Carbon 2015, 89, 31-40. [CrossRef]

28. O'Connor, D.; Peng, T.Y.; Zhang, J.L.; Tsang, D.C.; Alessi, D.S.; Shen, Z.T.; Bolan, N.S.; Hou, D.Y. Biochar application for the remediation of heavy metal polluted land: A review of in situ field trials. Sci. Total Environ. 2018, 619, 815-826. [CrossRef] [PubMed]

29. Zhao, B.; O'Connor, D.; Zhang, J.L.; Peng, T.Y.; Shen, Z.T.; Tsang, D.; Hou, D.Y. Effect of pyrolysis temperature, heating rate, and residence time on rapeseed stem derived biochar. J. Clean. Prod. 2018, 174, 977-987. [CrossRef]

30. O'Connor, D.; Peng, T.Y.; Li, G.H.; Wang, S.X.; Duan, L.; Mulder, J.; Cornelissen, G.; Cheng, Z.L.; Yang, S.M.; Hou, D.Y. Sulfur-modified rice husk biochar: A green method for the remediation of mercury contaminated soil. Sci. Total Environ. 2017, 621, 819-826. [CrossRef] [PubMed]

31. Shen, Z.T.; Hou, D.Y.; Zhao, B.; Xu, W.D.; Ok, Y.S.; Bolan, N.S.; Alessi, D.S. Stability of heavy metals in soil washing residue with and without biochar addition under accelerated ageing. Sci. Total Environ. 2018, 619, 185-193. [CrossRef] [PubMed]

32. Zhou, Y.M.; Gao, B.; Zimmerman, A.R.; Chen, H.; Zhang, M.; Cao, X.D. Biochar-supported zerovalent iron for removal of various contaminants from aqueous solutions. Bioresour. Technol. 2014, 152, 538-542. [CrossRef] [PubMed]

33. Tan, X.F.; Liu, Y.G.; Gu, Y.L.; Xu, Y.; Zeng, G.M.; Hu, X.J.; Liu, S.B.; Wang, X.; Liu, S.M.; Li, J. Biochar-based nano-composites for the decontamination of wastewater: A review. Bioresour. Technol. 2016, 212, 318-333. [CrossRef] [PubMed]

34. Yang, S.Y.; Yang, X.; Shao, X.T.; Niu, R.; Wang, L.L. Activated carbon catalyzed persulfate oxidation of Azo dye acid orange 7 at ambient temperature. J. Hazard. Mater. 2011, 186, 659-666. [CrossRef] [PubMed]

35. Pu, M.J.; Ma, Y.W.; Wan, J.Q.; Wang, Y.; Huang, M.Z.; Chen, Y.M. Fe/S doped granular activated carbon as a highly active heterogeneous persulfate catalyst toward the degradation of Orange $G$ and diethyl phthalate. J. Colloid Interface Sci. 2014, 418, 330-337. [CrossRef] [PubMed]

36. Li, Q.; Zhai, J.P.; Zhang, W.Y.; Wang, M.M.; Zhou, J. Kinetic studies of adsorption of Pb(II), Cr(III) and $\mathrm{Cu}(\mathrm{II})$ from aqueous solution by sawdust and modified peanut husk. J. Hazard. Mater. 2017, 141, $163-167$. [CrossRef] [PubMed]

37. Tanyildizi, M.S. Modeling of adsorption isotherms and kinetics of reactive dye from aqueous solution by peanut hull. Chem. Eng. J. 2011, 168, 1234-1240. [CrossRef]

38. Cheng, Q.M.; Huang, Q.; Khan, S.; Liu, Y.J.; Liao, Z.N.; Li, G.; Ok, Y.S. Adsorption of Cd by peanut husks and peanut husk biochar from aqueous solutions. Ecol. Eng. 2016, 87, 240-245. [CrossRef] 
39. Han, X.Y.; Chu, L.; Liu, S.M.; Chen, T.M.; Cheng, D.; Yan, J.L.; Cui, L.Q.; Quan, G.X. Removal of methylene blue from aqueous solution using porous biochar obtained by $\mathrm{KOH}$ activation of peanut shell biochar. BioResources 2015, 10, 2836-2849. [CrossRef]

40. Hou, D.Y.; Li, F.S. Complexities Surrounding China's Soil Action Plan. Land Degrad. Dev. 2017, 28, $2315-2320$. [CrossRef]

41. Hou, D.Y.; O'Connor, D.; Nathanail, P.; Tian, L.; Ma, Y. Integrated GIS and multivariate statistical analysis for regional scale assessment of heavy metal soil contamination: A critical review. Environ. Pollut. 2017, 231, 1188-1200. [CrossRef] [PubMed]

42. Hou, D.Y.; Al-Tabbaa, A. Sustainability: A new imperative in contaminated land remediation. Environ. Sci. Policy 2014, 39, 25-34. [CrossRef]

43. O'Connor, D.; Hou, D.; Ok, Y.S.; Song, Y.; Sarmah, A.; Li, X.; Tack, F.M. Sustainable in situ remediation of recalcitrant organic pollutants in groundwater with controlled release materials: A review. J. Control. Release 2018, 283, 200-213. [CrossRef] [PubMed]

44. Hussain, I.; Li, M.Y.; Zhang, Y.Q.; Li, Y.C.; Huang, S.B.; Du, X.D.; Liu, G.Q.; Hayat, W.; Anwar, N. Insights into the mechanism of persulfate activation with $\mathrm{nZVI} / \mathrm{BC}$ nanocomposite for the degradation of nonylphenol. Chem. Eng. J. 2017, 311, 163-172. [CrossRef]

45. American Public Health Association; American Water Works Association; Water Environment Federation. Standards Methods for the Examination of Water and Wastewater; American Public Health Association: Washington, DC, USA, 1998.

46. Liang, C.J.; Huang, C.F.; Mohanty, N.; Kurakalva, R.M. A rapid spectrophotometric determination of persulfate anion in ISCO. Chemosphere 2008, 73, 1540-1543. [CrossRef] [PubMed]

47. Gao, H.C.; Xiao, F.; Ching, C.B.; Duan, H.W. One-step electrochemical synthesis of PtNi nanoparticle-graphene nanocomposites for nonenzymatic amperometric glucose detection. ACS Appl. Mater. Interface 2011, 3, 3049-3057. [CrossRef] [PubMed]

48. Dong, H.; Zhang, C.; Hou, K.J.; Cheng, Y.J.; Deng, J.M.; Jiang, Z.; Tang, L.; Zeng, G.M. Removal of trichloroethylene by biochar supported nanoscale zero-valent iron in aqueous solution. Sep. Purif. Technol. 2017, 188, 188-196. [CrossRef]

49. Yan, J.C.; Han, L.; Gao, W.G.; Xue, S.; Chen, M.F. Biochar supported nanoscale zerovalent iron composite used as persulfate activator for removing trichloroethylene. Bioresour. Technol. 2015, 175, 269-274. [CrossRef] [PubMed]

50. Tang, J.C.; Lv, H.H.; Gong, Y.Y.; Huang, Y. Preparation and characterization of a novel graphene/biochar composite for aqueous phenanthrene and mercury removal. Bioresour. Technol. 2015, 196, 355-363. [CrossRef] [PubMed]

51. Inyang, M.; Gao, B.; Zimmerman, A.; Zhou, Y.M.; Cao, X.D. Sorption and cosorption of lead and sulfapyridine on carbon nanotube-modified biochars. Environ. Sci. Pollut. Res. 2015, 22, 1868-1876. [CrossRef] [PubMed]

52. Fang, G.D.; Liu, C.; Gao, J.; Dionysiou, D.D.; Zhou, D.M. Manipulation of Persistent Free Radicals in Biochar To Activate Persulfate for Contaminant Degradation. Environ. Sci. Technol. 2015, 9, 5645-5653. [CrossRef] [PubMed]

53. Nie, M.H.; Yang, Y.; Zhang, Z.J.; Yan, C.X.; Wang, X.N.; Li, H.J.; Dong, W.B. Degradation of chloramphenicol by thermally activated persulfate in aqueous solution. Chem. Eng. J. 2014, 246, 373-382. [CrossRef]

54. Potakis, N.; Frontistis, Z.; Antonopoulou, M.; Konstantinou, L.; Mantzavinos, D. Oxidation of bisphenol A in water by heat-activated persulfate. J. Environ. Manag. 2016, 195, 125-132. [CrossRef] [PubMed]

55. Liang, C.J.; Su, H.W. Identification of sulfate and hydroxyl radicals in thermally activated persulfate. Ind. Eng. Chem. Res. 2009, 48, 5558-5562. [CrossRef]

56. Furman, O.S.; Teel, A.L.; Ahmad, M.; Merker, M.C.; Watts, R.J. Effect of basicity on persulfate reactivity. J. Environ. Eng. 2011, 137, 241-247. [CrossRef]

57. Furman, O.S.; Teel, A.L.; Watts, R.J. Mechanism of base activation of persulfate. Environ. Sci. Technol. 2010, 44, 6423-6428. [CrossRef] [PubMed]

58. Chen, K.F.; Chang, Y.C.; Liu, K.Y. A kinetic and mechanistic study of the degradation of 1,2-dichloroethane and methyl tert-butyl ether using alkaline-activated persulfate oxidation. RSC Adv. 2016, 6, 75578-75587. [CrossRef] 
59. Zhou, L.C.; Ma, J.J.; Zhang, H.; Shao, Y.M.; Li, Y.F. Fabrication of magnetic carbon composites from peanut shells and its application as a heterogeneous Fenton catalyst in removal of methylene blue. Appl. Surf. Sci. 2015, 324, 490-498. [CrossRef]

60. Ouyang, D.; Yan, J.C.; Qian, L.B.; Chen, Y.; Han, L.; Su, A.Q.; Zhang, W.Y.; Ni, H.; Chen, M.F. Degradation of 1,4-Dioxane by biochar supported nano magnetite particles activating persulfate. Chemosphere 2017, 184, 609-617. [CrossRef] [PubMed]

61. Chen, L.; Peng, X.Z.; Liu, J.H.; Li, J.J.; Wu, F. Decolorization of Orange II in Aqueous Solution by an Fe(II)/sulfite System: Replacement of Persulfate. Ind. Eng. Chem. Res. 2012, 42, 13632-13638. [CrossRef]

(C) 2018 by the authors. Licensee MDPI, Basel, Switzerland. This article is an open access article distributed under the terms and conditions of the Creative Commons Attribution (CC BY) license (http://creativecommons.org/licenses/by/4.0/). 